\title{
Arnold Esch (2019). Von Venedig ins Heilige Land und nach Ägypten. Pilgerberichte als historische Quelle (Römische Quartalschrift, 2019, Bd.114, H.1-2, S.56-79. \\ ISSN 0035-7812)
}

Бузыкина И.Н.

Бузыкина И.Н., Музеи Московского Кремля. ORCID: 0000-0002-8717-8279, e-mail: irina.nik.buzykina@gmail.com

\section{(cc) BY 4.0}

Для цитирования: Бузыкина И.Н. Arnold Esch (2019). Von Venedig ins Heilige Land und nach Ägypten. Pilgerberichte als historische Quelle (Römische Quartalschrift, 2019, Band 114, Heft 1-2, S.56-79. ISSN 0035-7812). Обзор книги. Российский журнал истории Церкви. 2021;2(2):70-88. doi:10.15829/2686-973X-2021-58

\section{Arnold Esch (2019). Von Venedig ins Heilige Land und nach Ägypten. Pilgerberichte als historische Quelle (Römische Quartalschrift, 2019, Bd.114, H.1-2, S.56-79. ISSN 0035-7812)}

Irina N. Buzykina

Irina N. Buzykina, Moscow Kremlin Museums. ORCID: 0000-0002-8717-8279, e-mail: irina.nik.buzykina@gmail.com

For citation: Irina N. Buzykina. Arnold Esch (2019). Von Venedig ins Heilige Land und nach Ägypten. Pilgerberichte als historische Quelle (Römische Quartalschrift, 2019, Band 114, Heft 1-2, S.56-79. ISSN 0035-7812). Review. Russian Journal of Church History. 2021;2(2):70-88. (In Russ.). doi:10.15829/2686-973X-2021-58

В 144 томе Römische Quartalschrift опубликована статья Арнольда Эша, заслуженного профессора, директора Немецкого исторического института в Риме. Эш известен прежде всего как крупнейший специалист по истории позднеантичных и раннесредневековых дорог и их роли в торговых, военных и культурных отношениях Средиземноморского региона. Важное место в его исследованиях занимают паломнические маршруты, одному из которых и посвящена эта публикация: морской путь из Венеции в Святую Землю и на Синай, зафиксированный в многочисленных дорожных заметках позднесредневековых пилигримов разных сословий и наций.

В статье представлен обзор разнообразной и многоуровневой проблематики, которую предполагает изучение документов, связанных с путешествиями в Святую Землю: во введении Эш обращает внимание на широту спектра информации, которую историк может извлечь из них - ведь это не только констатация благочестивого намерения некой личности, но также весь исторический контекст, в котором оно реализовывалось: “экономическая история, история мореплавания, устройство Венецианской морской державы, зарождение глобального мышления из практических задач заморской торговли, события современной истории (турецкое заво- 
евание)". Стремление христианина побывать на земле, по которой некогда ходил Христос, сопряжено с высоким эмоциональным подъемом - здесь сказываются и испытания неизбежными дорожными тяготами, и непривычная, чуждая и завораживающая атмосфера Востока, и объективная опасность путешествия - даже в мирное время (Эш рассматривает в основном путевые заметки конца XV в., насыщенного трагическими событиями именно в этих водах, но о них ниже) у паломников оставался шанс не вернуться домой из-за болезней или фатальной неосторожности.

Повествование Эша построено в основном на двух типах источников. Помимо записей паломников (для описываемого в статье XV в. этот корпус из более чем 200 памятников $)^{1}$ с описанием дороги и пребывания в Святой земле он привлекает документы, благодаря которым подобные путешествия могли состояться (или не состояться): это счета, договоры о транспорте (грузов), а также опубликованные Немецким историческим институтом в Риме материалы Апостольской пенитенциарии².

Завершив обзор источников и их специфики, Эш приступает к описанию собственно пути. Отправная точка паломничества - Венеция, здесь в ожидании подходящего судна собираются благочестивые путники со всей Европы. До нее маршруты паломников из разных стран пролегали через альпийские перевалы - чей-то с запада через Мон-Сени ${ }^{3}$, чей-то - с севера через Большой Сен-Бернар, Сен-Готард или Бреннер. Как добирались до Венеции итальянские паломники, Эш не указывает, видимо, потому что опирается в основном на источники немецкого происхождения 4 . Помимо осознания необходимости преодолеть опасности и тяготы морского плавания, на берегу их настигают сугубо практические заботы: что делать с лошадью, где в чужом городе остановиться,

1 В примечаниях к статье автор демонстрирует многолетний опыт работы с архивами и изданиями паломнических сообщений, ссылаясь на заметки не только немецких, но итальянских, французских, английских пилигримов и адресуя заинтересованного читателя к изданиям первоисточников и их комментированным переводам, осуществлявшимся с середины XIX в. по начало XXI в. Например, знаменитый Evagatorium in Terrae Sanctae, Arabiae et Egypti peregrinationem Феликса Фабера: Hassler (1843) (лат.) Roob (1965) (нем.) и сборник актуальных исследований памятника Die Welt des Felix Fabri (2018).

2 Registri Matrimonialium et Diversorum 2-50 для понтификатов от Евгения IV до Александра VI. Упоминаемые дела зарегистрированы в разделе De diversis formis und De declaratoriis. Справочное издание по немецкому подразделению реестра: Repertorium Poenitentiariae Germanicum. Verzeichnis der in den Supplikenregistern der Pönitentiarie vorkommenden Personen, Kirchen und Orte des Deutschen Reiches, bearbeitet von L. Schmugge und Mitarbeitern, I. Eugen IV. (1998) - XI, Hadrian VI. (2018). В сноске приведена краткая библиография основных публикаций: Richard (1981), Europäische Reiseberichte (1994-2000), Cardini (2005), Fünf Palästina-Pilgerberichte (1998), проливающие свет на ранее малоизученные вопросы. Благодаря этим документам мы узнаем, например, больше о статусе, мотивации и личностях паломников, и, что особенно ценно, паломниц (да, Эш обращает внимание на известный факт, что после путешествия Эгерии сообщений, оставленных женщинами, на протяжении веков появляется не так уж много - их буквально можно перечесть по пальцам).

3 Перевал Мон-Сени в настоящее время разделяет французский департамент Савойя и итальянскую коммуну Сузы (округ Турин). Известен со времен поздней Античности, в частности, этой дорогой отправлялся Константин I в первый поход против Максенция, в Средневековье этим проходом через Альпы пользовались франкские короли, среди которых - Пипин Короткий и Карл Великий, а Генрих IV отправлялся этой дорогой в Каноссу. Первым “благоустроителем" перевала, предсказуемым образом, стал Наполеон I, по приказу которого здесь проложили проездную дорогу. Входит в систему паломнического пути Via Francigena.

${ }^{4}$ Прим. ред. - паломнические пути из германских земель "спускались" с Альп и шли вдоль реки По и ее притоков. 
чтобы не попасться мошенникам, как, в конце концов, обеспечить себе место на корабле? “Прежде чем вступить в венецианские владения, пилигримы должны были избавиться от своих коней, естественно, на суше: в большинстве случаев их продавали в Тревизо, чтобы затем на обратной дороге купить новых. Так каждый раз мы узнаем актуальные цены на лошадей в Северной Италии”. Это небольшая иллюстрация того, какого рода факты может содержать дорожная заметка и какую перспективу для исследования открывает массовость подобного материала: это всего лишь одно из многих общих мест паломнического нарратива - цены на товары и услуги. Учитывая важность торговли для Венецианской республики, эти данные также представляют определенный исследовательский интерес.

На развитость “туристической инфраструктуры” в Венеции XV в. указывает то, что иностранцу легко можно было найти постоялый двор, который держал бы его соотечественник (здесь Эш приводит часто цитируемый пассаж из Феликса Фабера о немецком дворе, где даже собака обладала ярко выраженным национальным чувством - немецкоговорящим гостям она виляла хвостом, а на иностранцев рычала).

Продолжая инфраструктурно-финансовую тему, Эш обращается к ключевой для всего паломничества проблеме - собственно, покупки “билета" в Святую Землю. Сделка с агентом того или иного судна обычно заключалась на площади Святого Марка, и зазывавших на борт обычно было больше, чем самих судов, готовых принять паломников. В XV столетии, в отличие от XI в., непосредственно перед Крестовыми походами, когда количество достигших Иерусалима путешественников в год исчислялось тысячами, в “высокий сезон"5 в начале лета в распоряжении пилигримов были обычно одиндва корабля. Агенты представляли интересы судовладельцев, которые все без исключения принадлежали к самым знатным и влиятельным семействам Венеции, дожам и кандидатам в достоинство дожей (Эш упоминает фамилии Лоредан, Контарини, Корнаро, Барбо). Каким условиям должен был удовлетворять полностью укомплектованный корабль, оправляющийся в Иерусалим, мы тоже узнаем из тех же источников (Эш приводит пример из сообщения Бернхарда фон Брейденбаха). Здесь среди важных факторов упомянута и экономическая выгода, получаемая от этого довольно-таки рискованного предприятия. Таким образом, путешествие на галере было далеко не бесплатным “удовольствием”, если можно так назвать морскую поездку на судне, из соображений скорости и окупаемости лишенном практически любой возможности предоставить больший уровень комфорта паломникам благородного происхождения. Но, с другой стороны, сама цель поездки предполагает смирение и равенство всех, как братьев и сестер во Христе. Цена “билета” 25-45 дукатов золотом сопоставима для наемного воина с годовым заработ-

\footnotetext{
5 "Сезон", насколько можно понять из статьи и приводимых источников, зависел напрямую не от христианского календаря, как сейчас, когда все стремятся попасть в Святую Землю на Пасху и Светлую неделю, с вариациями в пределах традиционных для разных культур способов вычисления Великого дня, a, скорее, от прихоти морских ветров (пусть галеры шли на веслах и не зависели в такой степени от силы и направления ветра, как парусные суда, в сезон штормов никто не отправлялся в путь из соображений безопасности) и в еще большей степени - от "расписания" движения судов, поставлявших специи из мест их производства в Египет.
} 
ком, для зажиточного мастера-каменщика - двухлетним доходом, для университетского профессора - примерно третьей частью годового содержания.

Другой вопрос - какими необходимыми в путешествии (ведь даже отправляясь за духовным опытом, нужно быть неким образом экипированным, как в прямом, так и в переносном смысле) вещами и сведениями должен запастись паломник - это и есть основное содержание паломнических записок, представляющих в ряде случаев вполне прикладное пособие для следующих поколений, отправляющихся в Святую Землю. В практической пользе собственно и заключалась популярность подобного рода изданий, которые очень рано начали публиковаться в печатном виде (точнее, практически сразу с возникновением книгопечатания): помимо важнейшей информации о святынях (и том, какие грехи искупаются их посещением - welche Ablässe man wo erhalten konnte), паломнический путеводитель обычно содержал “лайфхаки”, где и как дешевле обзавестись провизией, и краткий разговорник, содержавший расхожие (или не очень) слова и фразы на арабском языке. Здесь Эш отмечает забавный и очень характерный для межкультурной коммуникации момент - некоторые из “расхожих выражений” на самом деле оказываются весьма специфическими диалектизмами или непристойностями. Что, в принципе, в условиях нарастающей враждебности по отношению к христианам в Иерусалиме было неудивительной и предсказуемой реакцией. Вооружившись необходимыми знаниями, паломник покупал матрац (подержанный, конечно, чтобы по возвращении его снова продать), который будет служить ему постелью на корабле, и был готов к подвигам смирения. Все прелести морского плавания в условиях экстремальной тесноты, антисанитарии от скопления людей и животных (речь не только о вшах и крысах: еда, предлагаемая на корабле, была настолько отвратительной, что лучше было купить еще на твердой земле живую курочку и задушить ее собственноручно в случае голода) и угрозы force majeure (стихия, военное нападение) были гарантированы одинаково как простому монаху, так и рыцарю или соборному старосте. Но такова была цена скорости: речь идет о путешествии на галерах, на тот момент одном из самых мобильных и быстрых средств передвижения ${ }^{6}$. Тем не менее, развиваемая скорость совершенно не гарантировала определенности в сроках отправления и прибытия. Задержать отправление могли различные обстоятельства, паломники ждали неделями на берегу, а пристать в гавани Иоппии (Яффе) еще не означало в тот же день увидеть Иерусалим. Эш обращает внимание также и на то, что в каком-то смысле паломничество начиналось для благочестивых путешественников еще на венецианской земле, славившейся многими святынями, - тем более, что ожидание часто затягивалось на долгие недели.

Для менее сосредоточенных на духовной составляющей маршрута паломников Венеция представляла столь же богатый выбор удивительных и диковинных зрелищ: чего стоили сами городские каналы, роскошные дворцы, причудливые наряды аристократок. Эш отмечает, что национальное чувство, поддерживавшее уверенность в иностранных путешествен-

${ }^{6}$ В среднем - 4 недели. 
никах на берегу Венеции, оставалось с ними и на борту галеры: многие специально фиксировали имена и происхождение всех своих спутников очевидно, чтобы и дальше иметь возможность поддерживать контакты, явление, вполне понятное и современному человеку. Тем более, что за время плавания им в любом случае приходилось общаться друг с другом. О сосуществовании в замкнутом пространстве, зачастую в экстремально опасных условиях, представители разных сословий пишут предельно ясно: например, когда шторм описывается не цитатами из Вергилия, а простым человеческим языком. Некоторые подробности нелегкого быта паломников с определенной стороны объясняет малое количество женщин среди желающих посетить Святую Землю: в уточнение к сказанному выше про имена спутников Эш приводит некоторые сведения о женщинах-паломницах: “некая дама с маленьким сыном”, “шестеро благочестивых богатых дам, которые по причине почтенного возраста едва держались на ногах”. Из этого собирательного портрета исследователь может сделать некие выводы, правда очень приблизительные и условные. На протяжении многих веков практические единственным сообщением о поездке в Святую Землю из женской ретроспективы оставалось путешествие Эгерии в конце IV в. ${ }^{7}$ Из XV столетия до нас дошло только одно описание, оставленное англичанкой Марджери Кемп о паломничестве в 1414 г. Эш отмечает, что она запомнилась спутникам своим подчеркнуто экзальтированным поведением. Вполне возможно, что это был единственно возможный способ уберечься от невольных искушений, поджидающих еще не старую женщину в пути. Тем не менее, даже сообщение такой колоритной личности, как Марджери Кемп, добавляет мало сведений о происхождении, личностях и положении паломниц. Подобные недостающие сведения Эш предлагает черпать в источниках другого рода - документах Апостольской пенитенциарии ${ }^{8}$, органа, рассматривавшего в том числе и вопросы, непосредственно связанные с паломничествами.

Во-первых, это дела о разрешении от невыполненных обетов посетить святые места (необязательно Иерусалим, речь могла идти и о святынях на территории Европы).

Во-вторых, дела, связанные с контактами с нехристианами': в данном случае, мусульманским населением Святой Земли, с которым неизбежно, хотя бы в лице представителей власти, прибыв на корабле в Иоппию, сталкивались все паломники. Далее, именно из документов Пенитенциарии мы узнаем, при каких условиях женщин могли быть допущены в паломничество: логичным образом, в составе небольшой группы и в сопровождении достойных доверия мужчин (сын, священник). Довольно часто вдовы перенимали обет покой-

\footnotetext{
${ }^{7}$ О самой, пожалуй, знаменитой паломнице поздней Античности, современнице святых Августина и Иеронима известно немногое: практически ничего - о личности и имени (которое представляет собой научный консенсус между полудюжиной версий) и довольно точно - о дате путешествия: между 381 и 384 гг.

${ }_{8}$ Poenintentiarius generalis/major, совр. Sacra Paenitentiaria (Available at: https://www.vatican.va/roman curia/ tribunals/apost_penit/index.htm [Accesed on 11.06.2021]) - трибунал Римской курии, рассматривающий дела внутрицерковной юрисдикции: снятие отлучения от Церкви, других церковных прещений, издание индульгенций.

9 Об этом подробнее в другой статье автора: Esch 2018.
} 
ного супруга. Прошения от благочестивых женщин в архиве Пенитенциарии достаточно многочисленны, чтобы представить, как минимум, различные стороны их социального и финансового положения.

Из тех же источников мы черпаем сведения и о том, какие семейства из венецианской знати получали от Церкви разрешение (лицензию) ${ }^{10}$ на отправку кораблей с паломниками в Святую Землю. Помимо коллективного портрета самих пассажиров корабля, Эш описывает его груз, а также то, что́ на борт ни в коем случае не должно было попадать. Наверняка не единожды паломники сравнивали галеру с Ноевым ковчегом, а один пересчитал всех животных на борту, и оказалось их не меньше сотни. Что, собственно, неудивительно: если хлеб - это “жесткий, как кирпич, сухарь, полный жуками, червяками и пауками”, а мясо “настолько отвратительно, что никто из тех, кто его видел, не согласился бы его попробовать”, поскольку на забой шли самые слабые и больные животные, самым безопасным было озаботиться собственным “живым холодильником” (рис. 1.).

Категорически не рекомендовалось приносить с собой на борт какие бы то ни было железные предметы, вследствие действующего еще со времен Кре-

10 Автор статьи по вопросу получения церковной "визы" в нехристианские земли отсылает к изданию: Hartmann, G. (2012) Licencia apostolica intrandi terras Sarracenorum et communicandi cum eis. Die päpstlichen Register als Quelle für die spätmittelalterlichen Pilgerfahrten, in: Friedensnobelpreis und historische Grundlagenforschung. Ludwig Quidde und die Erschließung der kurialen Registerüberlieferung, hg. von M. Matheus, Berlin/ Boston, 243-277.

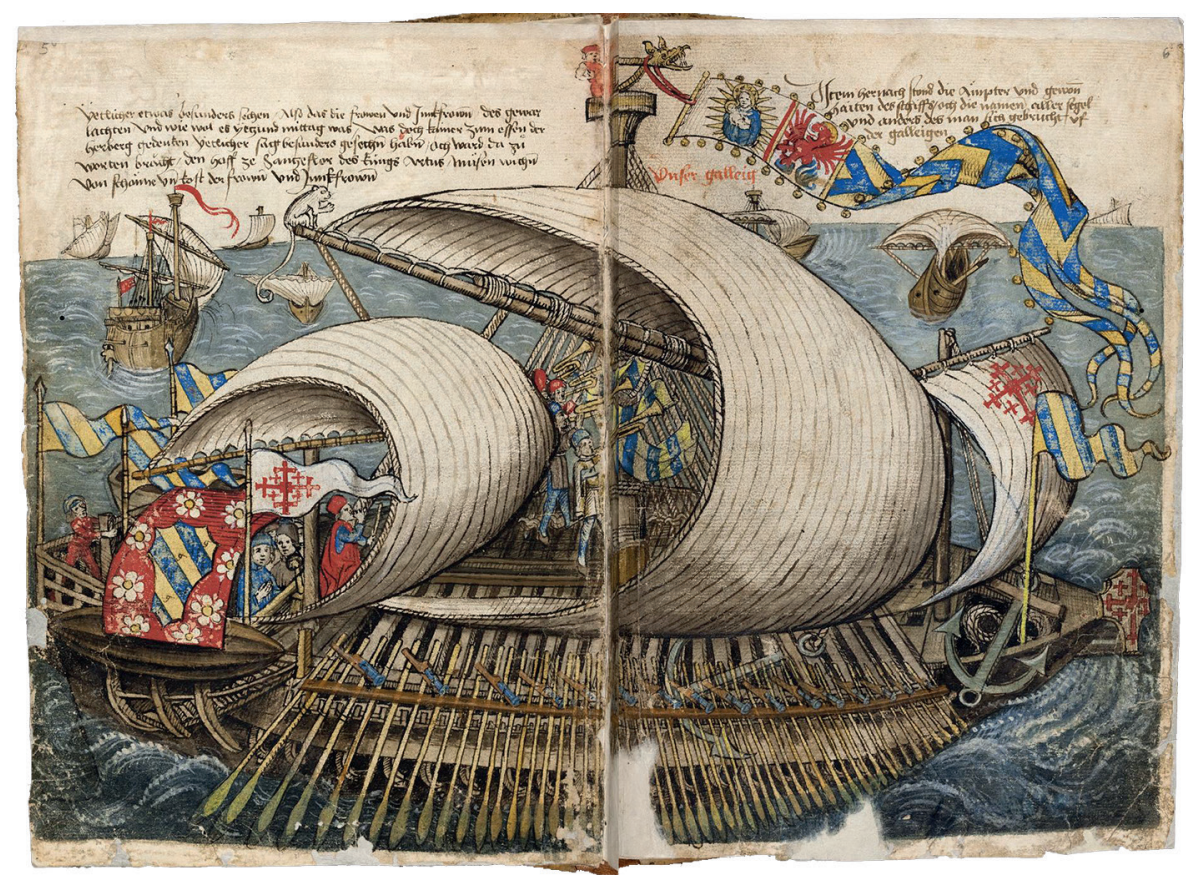

Рис. 1. Галера Агостино Контарини на парусах. Konrad Grünemberg: Beschreibung der Reise von Konstanz nach Jerusalem, 1487 (Cod St Peter pap 34. Digitalisat Badische landesbibliothek Karlsruhe). 
стовых походов эмбарго ${ }^{11}$. Любые попытки поставки железа (а также дерева и других материалов, необходимых для производства оружия) на Ближний Восток должны были строжайше пресекаться и караться отлучением от Церкви. Эш замечает, однако, что из документов все той же Пенитенциарии можно понять, что итальянским купцам все же удавалось продавать мусульманам дефицитный металл. Ведь иначе достичь положительного баланса в международной торговле с Востоком было бы просто невозможно. Тем более, что пряности, которые везли из Египта венецианцы, были не менее ценным и рискованным грузом. И запрет на железные предметы не оставался незамеченным наблюдательными паломниками: Эш отмечает курьезное мнение, что в Красном море корабли построены без единого гвоздя потому, что путь их лежит мимо легендарной магнитной горы, которая притягивала бы их к себе и вырывала из обшивки судна.

Впечатлениям и наблюдениям паломников об устройстве корабля Эш тоже уделяет внимание: далеко не все из всходивших на палубу и получавших свое место (отмеченное мелом прямо на досках) прежде сталкивались с морским судном такого типа. Галера характерна именно для Средиземноморской акватории, это узкое, длинное судно, с низкой осадкой и к тому же, помимо паруса, приводившееся в движение множеством чудовищной длины весел. В традициях навигации древних времен, с которыми этот тип морского транспорта непосредственно связан, передвигалась галера исключительно вдоль берега. Стабильная скорость, с которой такой корабль передвигался, достигалась мышечной силой двух сотен гребцов - “живого мотора”, занимавшего значительную часть пространства. Грузоподъемность торговой галеры была, таким образом, весьма ограничена, что сказывалось и на ее рентабельности. Однако венецианские купцы рассчитывали, как было сказано выше, именно на компактные и очень ценные грузы.

Документальные сведения о владельцах галер освещают первостепенную роль, которую играла Католическая церковь в этом рискованном и прибыльном предприятии: любой судовладелец, решивший снарядить корабль для путешествия на Восток, должен был получить licentia visitandi для себя и своих пассажиров. Чаще всего в этих документах встречаются фамилии конкурирующих семейств Лоредан и Контарини (рис. 2). Сначала путь пролегал вдоль побережья Далмации в сторону острова Корфу (рис. 3), затем на юг, огибая материковую Грецию, вокруг материковой Греции к островам Криту и Родосу, всегда от одной венецианской военной крепости к другой. Эш подчеркивает, что мощь венецианского владычества, собственно, и основывалась на этих укреплениях, господствовавших над морскими путями, крепостях без особой связи с остальными землями тех побережий и островов, на которых они были построены (в оригинале - игра слов: употребленный термин Hinterland обозначает как глубокий тыл, в военной терминологии, так и непосредственно прилежащие к фактории земли). Именно такая

\footnotetext{
11 Прим. ред. - запреты на торговлю железом с сарацинами издавались Соборами. Последнее упоминание содержится в документах II Лионского собора (1272-1274). После запрета отправления культа Магомета в христианских землях на Вьеннском соборе (1311-1312), слово "сарацин" исчезает из документов, а Пятый латеранский собор (1512-1517) использует слово “турок”, но уже не издает предписаний запрета торговли.
} 


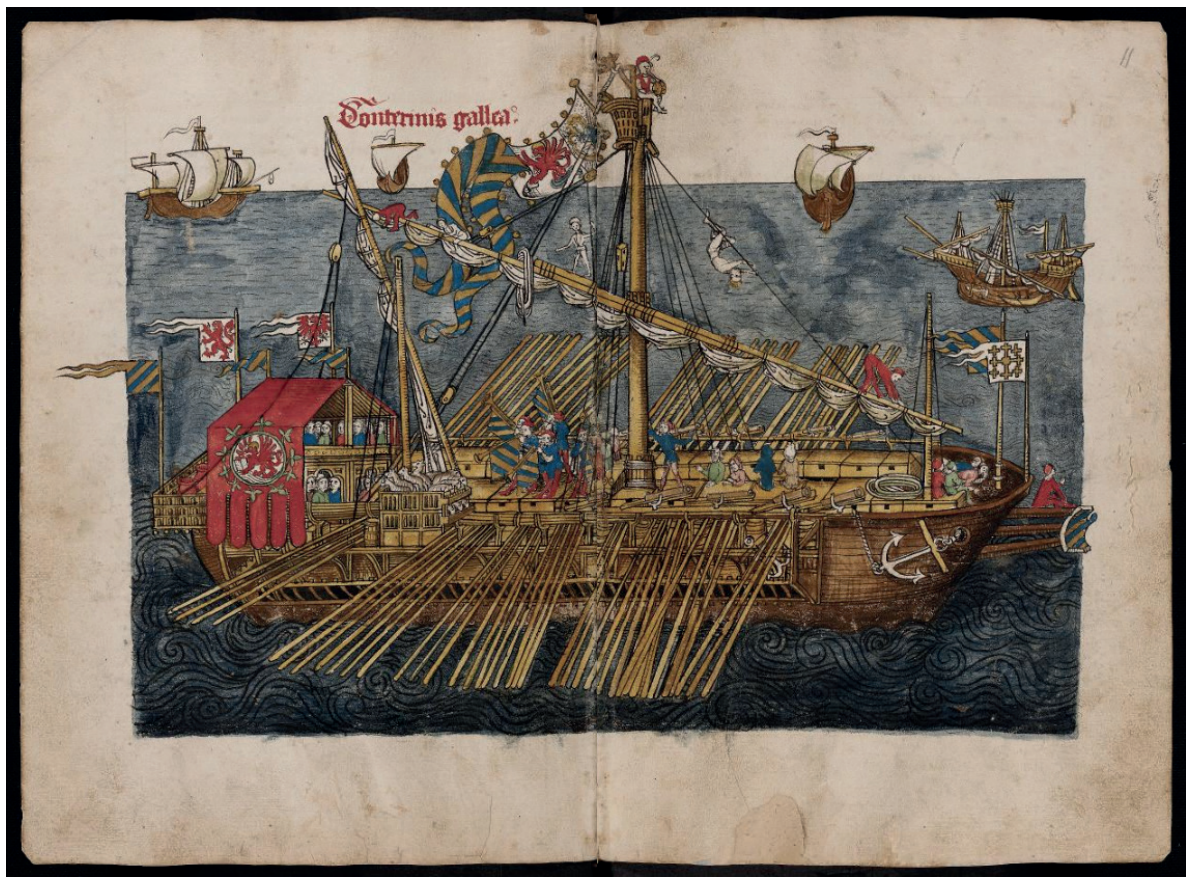

Рис. 2. Галера Агостино Контарини. Konrad Grünemberg: Bericht über die Pilgerfahrt ins heilige Land, 1486 [https://dhb.thulb.uni-jena.de/ufb_cbu_00025778 Digitale Historische Bibliotek Erfurt/Gotha].

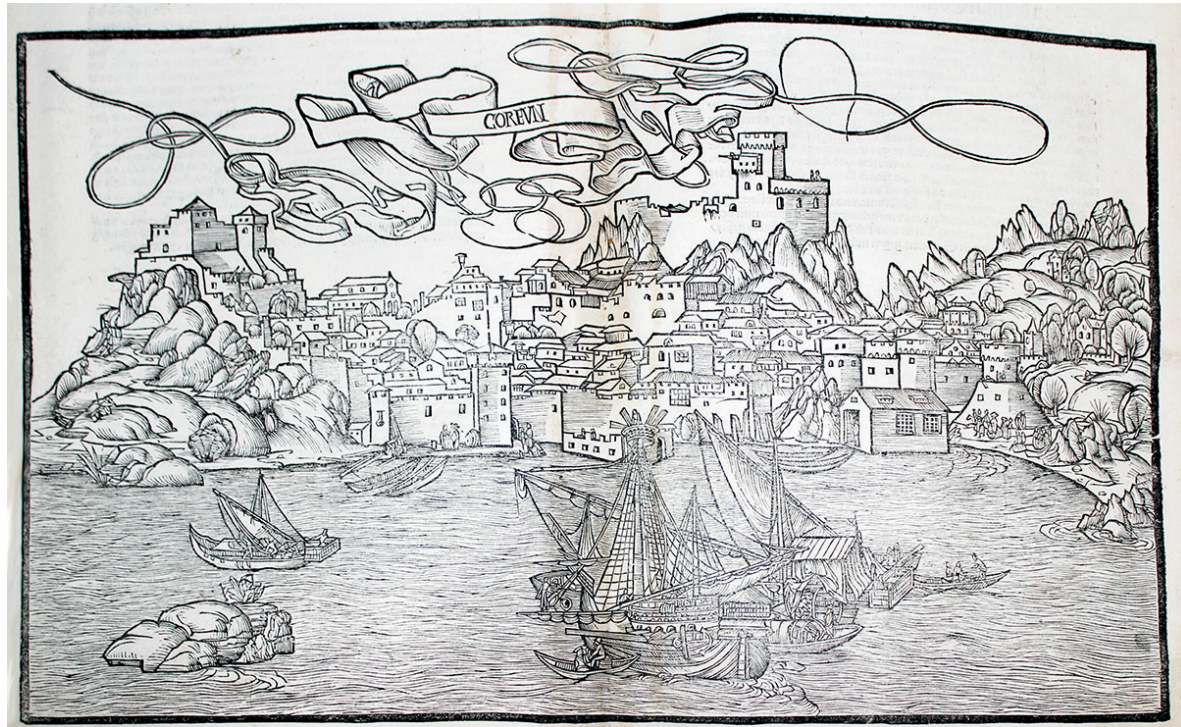

Рис. 3. Вид острова Корфу. Bernhard von Breydenbach: Die heilige[n] reysen gein Jherusalem zu dem heiligen Grab vnd furbaß zu der hochgelobten jungfrowen vnd merteryn sant katheryn, [Speyer], [ca. 1505] (библиотека ИосифоВолоцкого монастыря). 


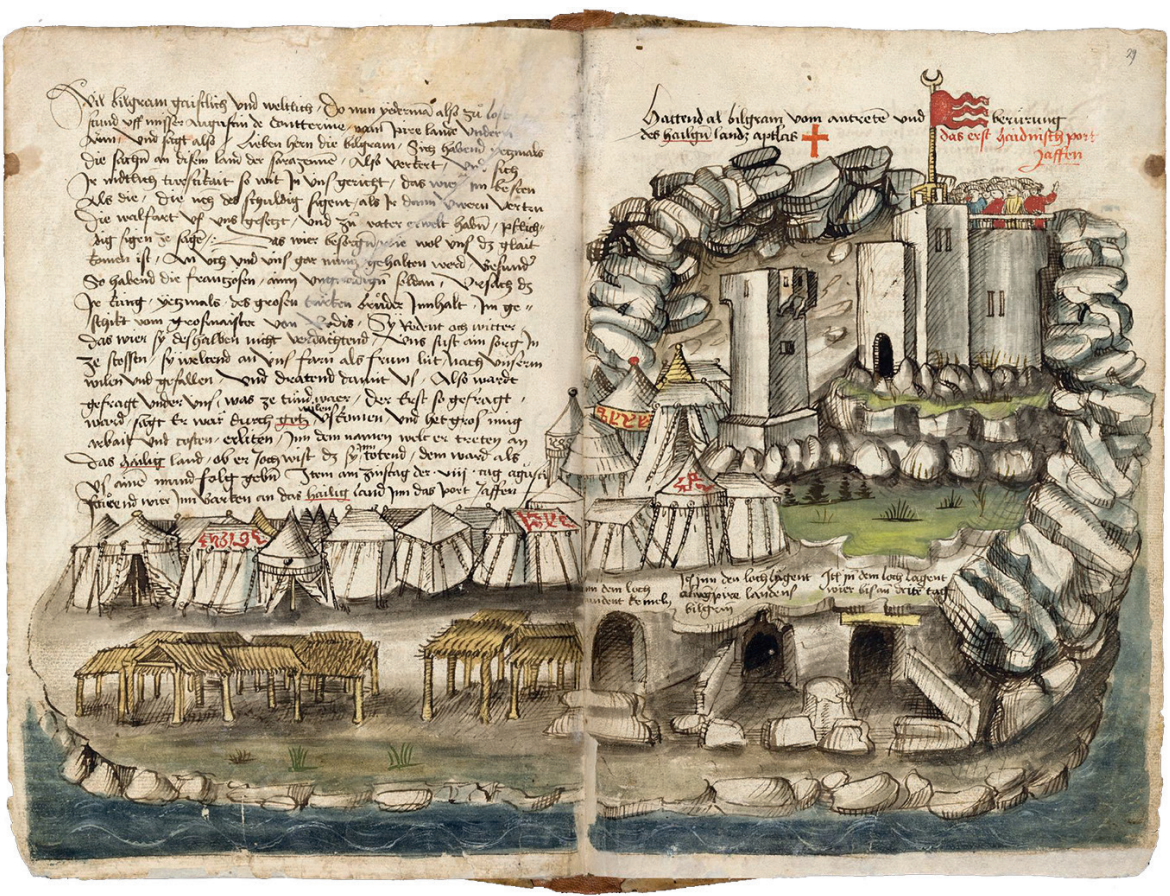

Pис. 4. ЯФФа с моря. Konrad Grünemberg: Beschreibung der Reise von Konstanz nach Jerusalem 1487 (Cod St Peter pap 34. Digitalisat Badische Landesbibliothek Karlsruhe).

избирательность венецианцев позволила им продержаться достаточно продолжительное время в окружении все более плотного турецкого присутствия, которое паломники, плывшие вдоль побережья, не могли не замечать (рис. 4). В последние десятилетия XV в. ситуация была уже настолько накалена, что в некоторые годы в паломничество лучше было вовсе не отправляться. Но пока венецианское владычество сохраняло свои позиции, пилигримы могли чувствовать себя в безопасности, спускаясь на берег во время остановок в порту Модоне (современная Метони, Мессения, Пелопоннес) (рис. 5) в Греции или Ханье на Крите (Кандия).

На Кипре путешественники получали первые экзотические впечатления - диковинные растения, непохожая на привычную жителю Европы городская застройка, и знакомились с местными святынями: здесь хранился палец Иоанна Крестителя, которым тот указывал на Спасителя, и пять гвоздей от Истинного Креста. Скуку, которая была неизбежной в длительном путешествии, могли развеять приходившиеся на это время праздники например, на Иванов день (24 или 25 июня) на реях зажигали фонари и даже, как пишет Эш, правда, без ссылок на источники, на палубе танцевали. Поскольку маршрут галеры проходил до самого Эгейского моря вдоль берега, на горизонте практически всегда можно было увидеть что-то достойное внимания. “Вот остров, с которого Парис увез Елену”, - эта реплика неизменно сопровождала прохождение мимо Киферы. Несомненно, это очень важная информация, потому что больше Античность никак не фигурирует. 


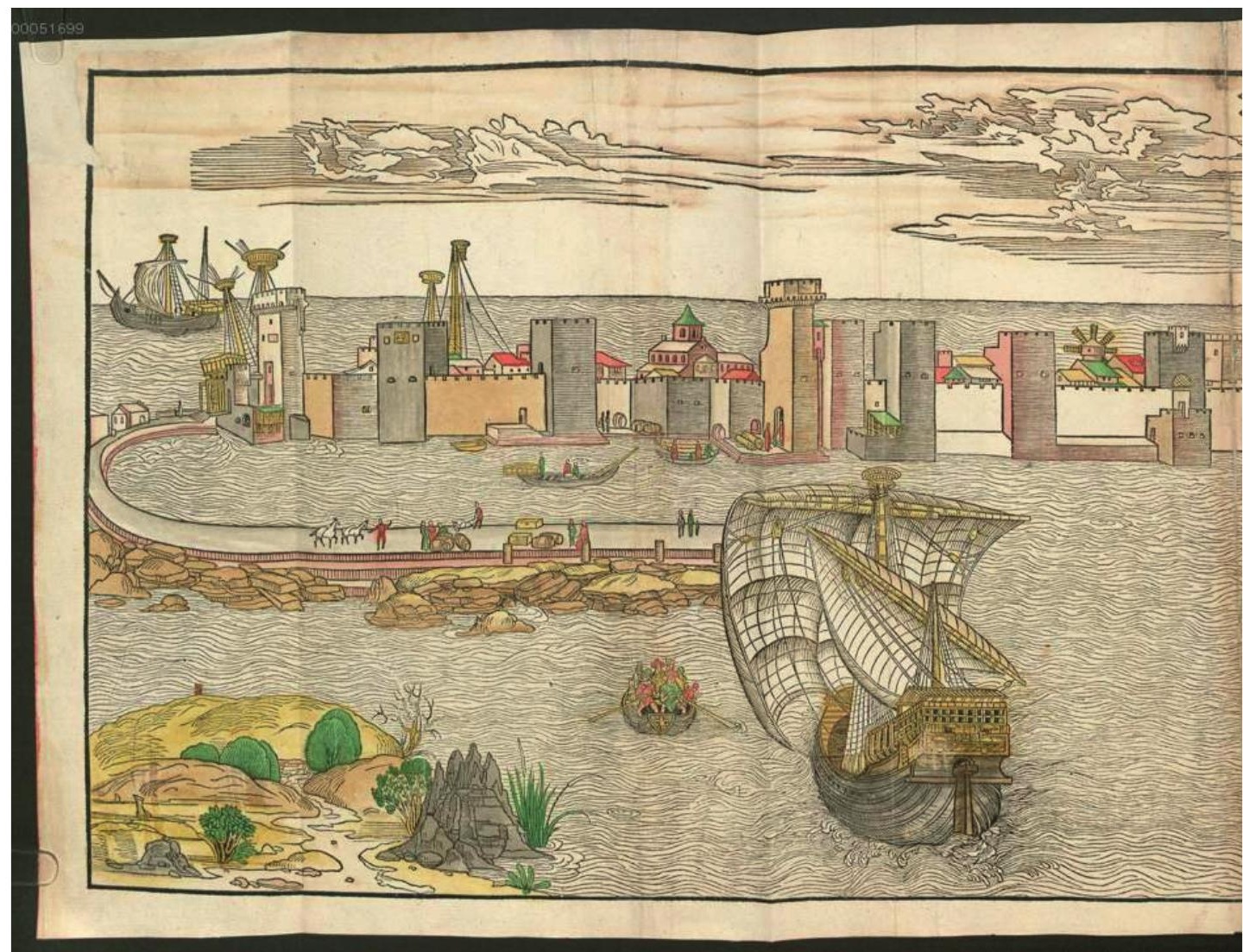

Diggitalisierung gefördert durch die Deutsche Forsehungegemeinscl

Рис. 5. Порт Модони. Bernhard von Breydenbach: Die heyligen reyßen gen Jherusalem zu dem heiligen grab, Mainz, 1486. (Digitalisat Baye

Брейденбах и Грюненберг знали про Родос, что на Родосе был Колосс, благодаря Посланию к Колоссянам. Однако более актуальной повесткой, нежели Троянская война или новозаветные события, выступало турецкое завоевание: с каждым новым путешествием вдоль побережья на нем все больше территорий оказывалось перешедшими под мусульманское владычество. Во второй половине XV столетия, отмечает автор, паломнический маршрут проходил уже преимущественно по враждебной территории. Описания пилигримов из 1480 г. фиксируют состояние Родоса непосредственно после кровавой осады Мехмедом II Фатихом: в тот раз рыцари-иоанниты героически сдержали натиск турок. Следуюшая осада, 1522 г., оказалась роковой: оставшимся в живых рыцарям пришлось оставить Родос и обосноваться на Мальте.

Перенесшись примерно на четверть века назад, к паломническому маршруту Эш эффектно присоединяет ключевое для истории Средних веков событие. Когда в начале июня 1453 г. паломническая галера огибала южную оконечность Греции, навстречу ей показались три других венецианских судна, с которых сообщили о падении Константинополя. Таки образом, следовавшие в Святую Землю паломники узнали о катастрофе, 
Когда спустя примерно шесть недель плавания на горизонте появлялись очертания побережья Святой Земли все на палубе преклоняли колени и пели благодарственный гимн Te Deum. Однако Иерусалим увидеть им предстояло еще нескоро: порой требовалось несколько дней (до двух недель!) ожидания, пока представитель местной власти даст разрешение паломникам покинуть судно.

Если понесенные раньше тяготы пути были страданием, то невзгоды, которые ждали по прибытии - издевательством. Но именно с того момента, как судно прибывало в Иоппию (Яффу), путешественники становились настоящими паломниками: спускаясь на Святую Землю, надлежало оставить титулы и звания, и причиной тому не только христианское смирение. Рыцарю и графу лучше было стать просто „братьями” в том числе и для того, чтобы избежать дополнительных поборов и вымогательств со стороны местных властей, должностных лиц и просто мошенников. Паломников размещали на твердой земле в некой античной развалине, которую упоминают все сообщения, и здесь под неусыпным надзором они проводили еще несколько дней.

Очевидно, что арабское и турецкое население не питало особого уважения к европейским пришельцам и цели их путешествия, однако в регулярных визитах христиан определенно можно было усмотреть источник дохода. Способы дополнительно нажиться на “туристической группе" пятисотлетней давности не сильно отличаются от современных уловок: "Хорошо, у вас есть пропуск. А у ослов ваших - нет, поэтому они останутся здесь". Или так: “Поскольку вы сказали, что не можете заплатить 100 дукатов, то завтра заплатите 200” - цитирует Эш сообщение одного из паломников 1496 г. Подобные незамысловатые, но совершенно безнаказанные унижения усугубляли ощущение беззащитности и произвола, в который окунался паломник, сошедший с венецианского корабля и оста-

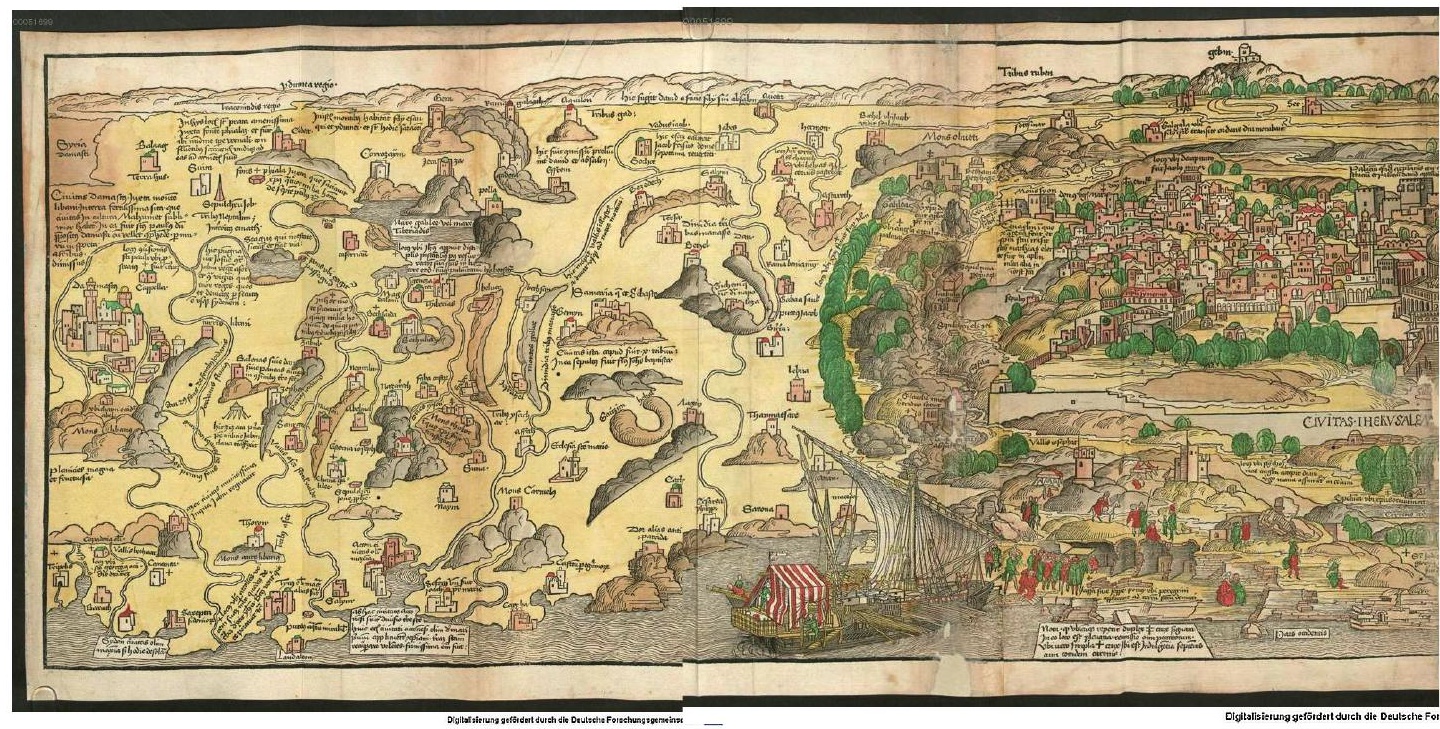

Рис. 6. Святая земля со станциями, карта. Bernhard von Breydenbach: Die heyligen reyßen gen Jherusalem zu dem heiligen grab, Mainz, 
вивший на нем свой титул, регалии и оружие. Простого пилигрима ждали на Святой Земле унижения, совершенно не способствовавшие пересмотру того образа мусульманина, который был ему знаком по рассказам.

Как уже было сказано, право передвижения по Святой Земле нужно было получить не только от Папского престола, но и непосредственно на месте. До тех пор, пока владелец галеры торговался с арабским чиновником, паломники не могли покинуть Яффу, точнее, ту самую античную развалину.

Венецианцы старались установить максимально низкую цену за право прохода, поскольку необходимый откуп уже входил в цену “билета”, чтобы само предприятие не просто самоокупилось, но и могло принести прибыль, - отмечает Эш меркантильный интерес организаторов паломнических поездок. Когда согласие, наконец, достигалось, паломники получали подписанные непривычным арабским письмом грамоты. Один паломник из Констанца предположил, что на документе по-арабски написано его имя. Это было бы логично, если бы речь шла об удостоверении привилегий некого лица в христианской стране. В Палестине имя паломника никого не интересовало, принципиальным было, выдан документ на право перемещения правомочным чиновником или это подделка, поэтому на патенте стояло имя представителя местной “таможни”.

Засвидетельствовав свое право передвижения, христианские паломники должны были дождаться отца-провожатого из братьев францисканцев, проживавших в монастыре на горе Сион в Иерусалиме. Монах должен был не только встретить и проводить группу, но и обучить элементарным правилам поведения в мусульманском мире. Среди обычных предписаний Эш отмечает настоятельное пожелание не царапать повсюду на стенах свои имена. Как это обычно бывает, любой запрет возникает не безосновательно: и здесь мы имеем письменные свидетельства о некоем паломнике, всегда носив-

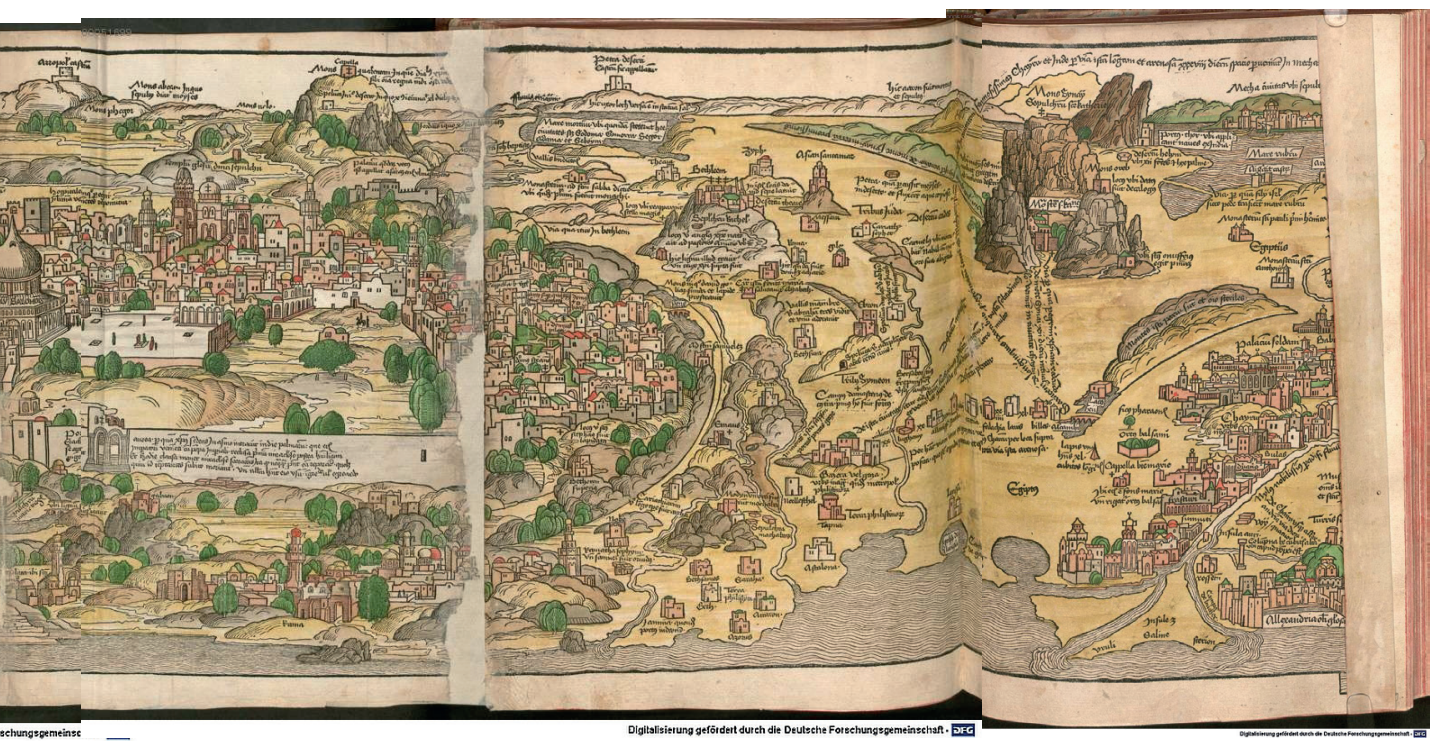

1486. (Digitalisat Bayerische Staatsbibliothek). 
шем в кошельке кусок красного камня, и о выцарапанных на стенах именах и даже гербах. Если подобные следы достаточно старинны, мы не критикуем их, а воспринимаем как исторические свидетельства, и почтительно называем этих “писателей” историческими фигурами, иронично замечает Эш. Следами пребывания исторических фигур покрыты колонны базилики Рождества в Вифлееме ${ }^{12}$, стены храма Гроба Господня и др.

Из Иоппии-Яффы паломники отправлялись в Иерусалим, этот путь был несравненно короче, чем то, что им уже пришлось одолеть. Размещались они обычно или во францисканской обители, из которой приходил провожатый, или в госпитале иоаннитов возле храма Гроба Господня. На поклонение величайшим святыням христианства людям, проделавшим долгий путь к Земле, по которой ступали ноги Спасителя, отводилось не так много времени (иногда всего 10 дней): хозяева галер не могли оплачивать долгий простой судна и его “мотора" - полутора сотен гребцов, которые нуждались в жилье и пище. К тому же, помимо посещения Иерусалима, галерные рейсы предполагали другое предприятие, приносившее основной доход их владельцам, а именно - торговлю пряностями. Поэтому расчет был примерно таков: чем скорее паломники вновь взойдут на борт корабля, тем лучше для судовладельца.

Пребывание паломников в Палестине удостоверялось Кустодией Святой Земли в лице все тех же францисканцев на протяжении веков вплоть до нашего времени. Примечательно, что свидетельства о паломничестве первым протестантам были выданы тем же порядком. С точки зрения Эша, присутствие протестантских паломников на венецианских галерах не является чем-то странным в свете источников, подтверждающих активное присутствие немецких купцов в зарубежной торговле, которую контролировала Венеция в рассматриваемое время, несмотря на скептическое отношение отца Реформации Мартина Лютера к практике посещения святынь. Эш приводит актуальную и довольно обширную библиографию к вопросу о роли Реформации в венецианской монополии на паломнические поездки ${ }^{13}$. В первом сообщении протестантского паломника, относящемся к началу 1550-х гг. примечательным с точки зрения Эша является даже не то, о чем путешественник пишет, а скорее то, что в этом описании отсутствует: у швейцарца Даниеля Эклина ${ }^{14}$ еще нет язвительных замечаний в адрес католической практики паломничества.

О святых местах, которые паломники посещали, написано достаточно. Они отмечены во всех путеводителях и отчетах, как и индульгенции, которые были связаны с каждой из станций. В этих пунктах, подчеркивает Эш,

\footnotetext{
12 Первая церковь на предполагаемом месте Рождества Спасителя была построена по приказанию матери императора Константина императрицы Елены.

${ }^{13}$ Например, Protestanten zwischen Venedig und Rom (2013), особенно подчеркивает в этом сборнике статью S. Oswald'a и S. Seidel Menchi; а также статью Schmidt, 2001:105-120, опубликованную в сборнике Inquisition, Index, Zensur. Wissenskulturen der Neuzeit im Widerstreit; и собственную публикацию Esch, 2014:129-142. Подробнее о немецком присутствии в Венеции автор отсылает к книге Braunstein (2016).

14 Эш отсылает заинтересованного читателя к научному комментированному изданию этого источника: Schiendorfer (2014) (Available at: https://www.researchgate.net/publication/280705165_Daniel_Ecklin_1532_-_211564_Reise_zum_ heiligen_Grab_Nach_der_Druckausgabe_Basel_Samuel_Apiarius_1575_transkribiert_und_kommentiert_von_Max Schiendorfer [Accessed on 11.06.2021]).
} 
все известные сообщения максимально схожи. Существуют даже карты Иерусалима, на которых отмечены святыни с мерой отпущения грехов: крест - обычная, 7 лет и 7 раз по 40 дней, в честь дней, которые Христос постился в пустыне, два креста - для двойного или полного отпущения грехов (рис. 6). И здесь Эш не проходит мимо забавной подробности, относящейся к практике паломничества: довольно рано сложилась традиция при посещении Иосафатовой долины, предполагаемого места Страшного суда, заранее “бронировать места”. Первые упоминания об этом обычае относятся к XII в., у Оттона Фрейзингенского (Chronica VIII 18), а некий швабский паломник (очевидно, Эш предполагает, что читатель угадает, кто именно) выразил сомнение, что долина вместит не то что всех христиан, но хотя бы его соотечественников. Отдельно, хоть и вскользь упоминает автор статьи о том, что среди особо почитаемых мест, которые, конечно, отмечены во всех путеводителях и паломнических книгах, довольно часто из программы выпадало посещение реки Иордан, места крещения Иисуса (рис. 7 и 8). Паломничество могло быть сокращено ровно по той же причине, что и в настоящее время - опасность нападения, которой подвергались безоружные христиане.

Едва ли в рассказе о путешествиях в Святую Землю можно обойтись без упоминания практики паломнических реликвий и сувениров. Эш упоминает самые распространенные из них - четки, пояски, другие

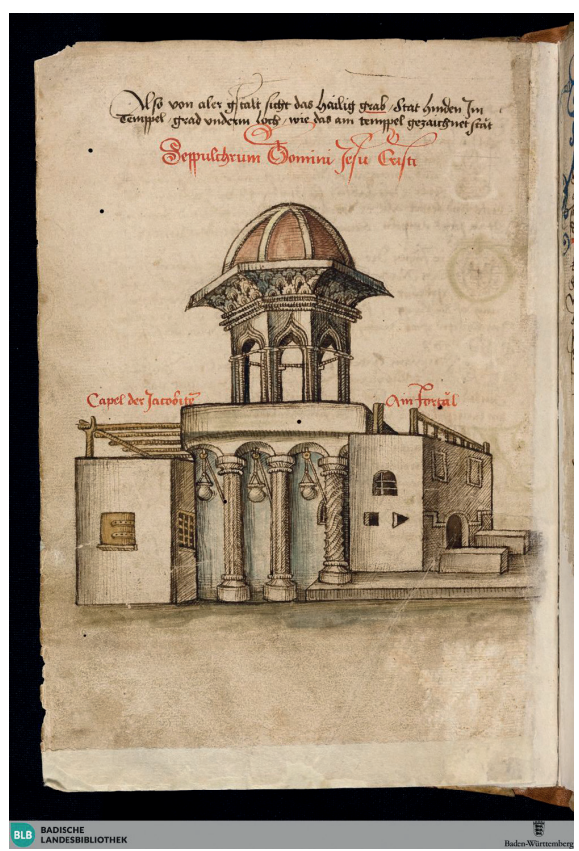

Рис. 7. Кувуклия Гроба Господня. Konrad Grünemberg: Beschreibung der Reise von Konstanz nach Jerusalem 1487 (Cod St Peter pap 34. Digitalisat Badische Landesbibliothek Karlsruhe).

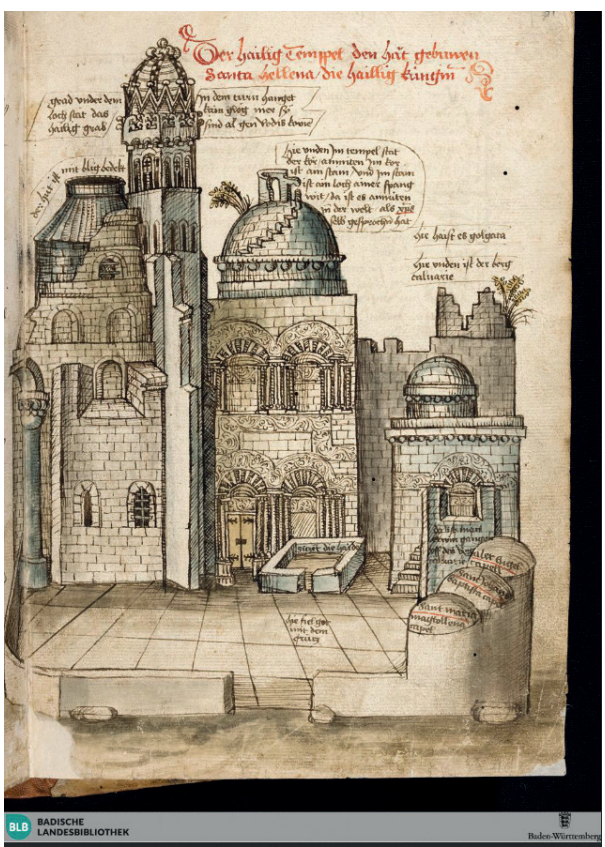

Рис. 8. Храм Гроба Господня в Иерусалиме. Konrad Grünemberg: Beschreibung der Reise von Konstanz nach Jerusalem 1487 (Cod St Peter pap 34. Digitalisat Badische Landesbibliothek Karlsruhe). 
осязаемые вещи, которые чаще всего привозили на родину из поездки. Обычно все эти приобретения перечислены в описании паломничества, с указанием места и количества. Помимо материальности, памятный предмет должен обладать и символическим значением, которое закладывалось в категорию "меры” - Гроба Господня, например, и привязкой к точно идентифицируемой локации святыни (например, изображение плата Вероники на паломническом значке указывает на факт посещения Рима, а пятикратное изображение креста - Иерусалима). Читателя, интересующегося тем, как эти значки выглядели, Эш отсылает к портрету швейцарца Петера Фюсли в художественном музее Золотурна, который пожелал изобразить себя со всеми семью паломническими знаками. Изображения плата Вероники на шапках паломников можно увидеть на фреске в базилике Санта Мария дельи Анджели в Ассизи ${ }^{15}$ (рис. 9).

Обратный путь был тоже полон приключений. Особенное внимание Эш уделяет экономическому аспекту путешествия, важность которого

${ }^{15}$ Автор обзора благодарит за возможность сослаться на эту деталь д-ра Санию Гукову, обратившую на нее внимание в своей еще не опубликованной монографии.

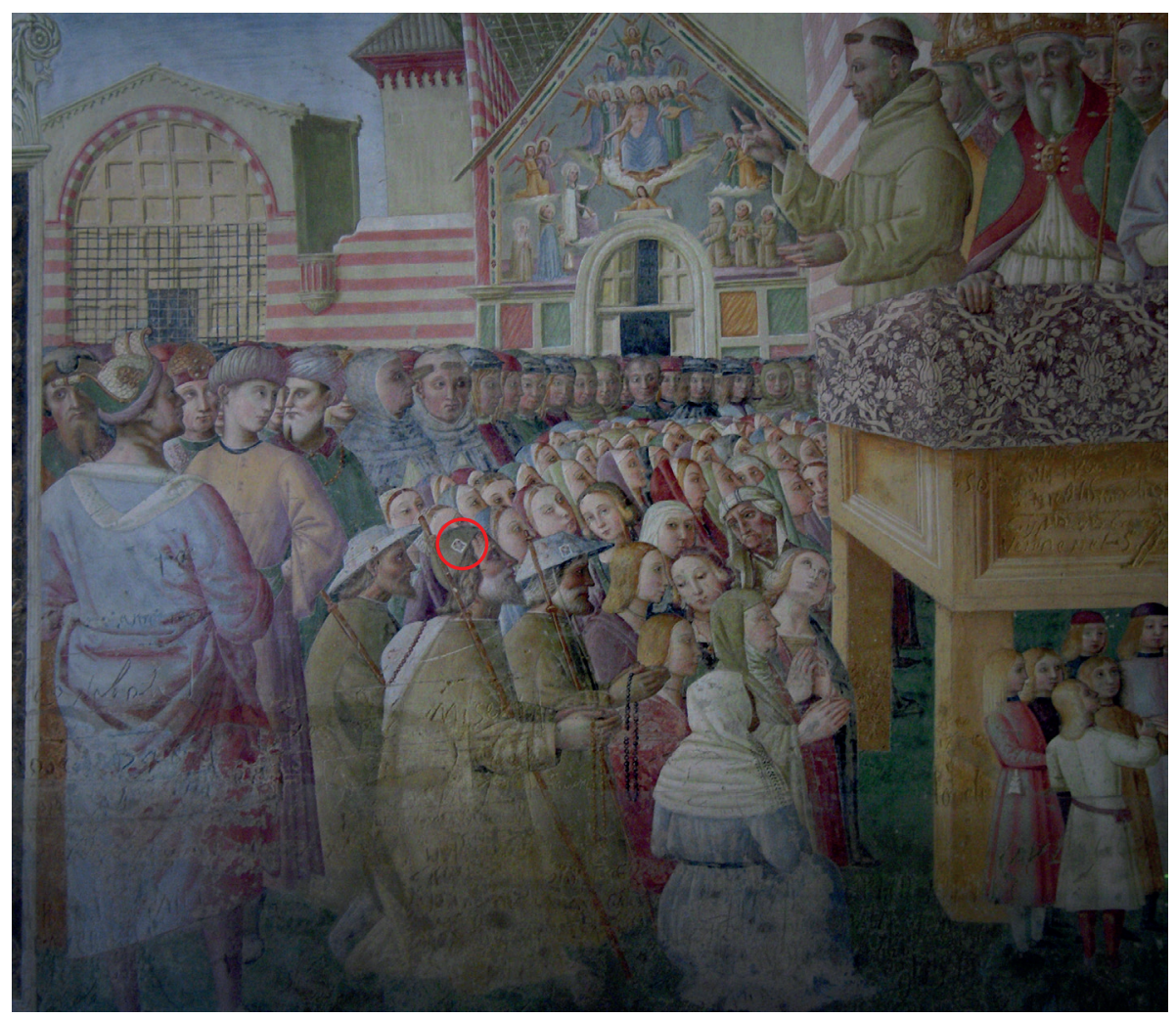

Рис. 9. Тиберио из Ассизи. Деталь фрески из Санта Мария дельи Анджели в Ассизи (creative commons license, wikipedia). 1518. 
раскрывалась как раз по пути из Иерусалима. Как раз сообщения о пути из Святой Земли в Венецию дают более полное представление о реалиях внешней торговли в позднем Средневековье. Паломники становились свидетелями разных ситуаций, которые они фиксировали в своих отчетах. В частности, им приходилось наблюдать и разные запрещенные практики: продажу железа и железных изделий туркам, торговлю людьми рабами-маврами. Были истории печальные, когда в штормах (которые на пути обратно никто не отменял) погибал ценный груз (например, клетки с экзотическими птицами), или забавные, демонстрирующие смекалку и изобретательность торговцев (например, на одной из галер, следовавших из Модони в Венецию, был описан (это сообщение Феликса Фабера) груз из 5000 свиных туш, вставленных по принципу матрешки одна в другую). Однако даже тысячи свиных туш или живых попугаев не могли принести той прибыли, которую давала торговля специями.

На обратном пути некоторые пилигримы меняли маршрут и отправлялись не прямиком домой, а через Египет, где можно было посетить знаменитый монастырь святой Екатерины на Синае. Этот вариант был достаточно распространен (например, тот же Брейденбах использовал эту возможность) и прекрасно описан, что предоставило историкам источники не только относительно положения христиан на территориях, подвластных мусульманам, но и о различных торговых, экономических и культурных аспектах.

Помимо сведений о взаимоотношениях Венеции и Европы в целом (посредством венецианских галер) с Ближним Востоком благодаря этому “крюку” паломнического маршрута исследователь получает информацию также и об Африке и Индии, входивших в логистическую схему несколько иного характера, а именно, торговли специями. Неудивительно, что среди паломников было много людей, которыми двигало не столько христианское благочестие, сколько коммерческий интерес, который, кстати, тщательно сдерживался венецианской монополией, не пускавшей европейских купцов за пределы своей гавани.

Следующим пределом европейской торговли был порт Александрии Египетской, дальше вглубь Азии проникновение христиан было запрещено ${ }^{16}$. В частности, для немецких купцов путешествие с заездом на Синай было, пожалуй, единственной возможностью приблизиться к баснословному источнику богатства, которое можно было купить по приемлемой цене. Как пишет Эш, когда паломники-торговцы оказывались на Синае, им открывалась (в прямом и переносном смыслах) захватывающая перспектива: далеко внизу, на северном краю Красного моря они могли видеть корабли, прибывшие из Индии, в которой, как говорили, можно было “мешок муки обменять на мешок перца”. По пути с Синая в Александрию через Суэцкий перешеек паломники могли наблюдать караваны по 500-600 верблюдов, нагруженных специями, а также другие удивительные достопримечательности - к примеру, следы канала, соединявшего

${ }^{16}$ Здесь Эш упоминает историю итальянца Никколо Конти, который ради путешествия в Индию и Китай принял ислам, а затем принес покаяние папе Евгению IV. 
Нил с Красным морем, прорытого еще во времена египетских фараонов. И, конечно же, внимательный и здравомыслящий путешественник не мог не оценить потенциал для международного торговли, который был бы реализован, не будь канал погребен под многовековыми наносами пустынного песка: “кораблем можно было добраться из Англии, Брюгге во Фландрии, Франции и других городов кроме Генуи и Венеции, прямо до Александрии, а из Александрии по Нилу до Красного моря, а оттуда через Аравию и Мавританию до Индии со всеми купеческими делами" ${ }^{17}$.

А в Александрии на рейде паломников ждали... венецианские галеры, которые прибыли в египетскую гавань, конечно же, не ради них, а потому, что маршруты и расписания движения венецианских судов ориентировались на торговлю специями, а значит, на прибытие в александрийский порт кораблей с пряностями из Аравии и Индии. И, как подчеркивает автор, особая конструкция галеры имела решающую роль: передвижение между Аравией и Индией практически невозможно на морских парусных судах из-за сезонных ветров-муссонов. Для пилигримов пятнадцатого столетия эта взаимосвязь между поставками специй из Индии и отправлением венецианских галер в Европу была, конечно же, само самой разумеющейся, как и для местных должностных лиц, контролировавших передвижения европейцев (и по возможности спекулировавших на них) по побережью Африки и Азии. Галеры отправлялись в Венецию нагруженными высоколиквидным товаром до отказа, поэтому у путешественников был реальный шанс остаться на берегу.

Возможно, это было не самой ужасающей перспективой, поскольку в Александрии у венецианцев были два хорошо оборудованные и укрепленные подворья - “фондако” (как и у немцев в Венеции возле моста Риальто, напоминает Эш читателю), со складами, собственными постоялыми дворами и всей необходимой инфраструктурой. Только в отличие от Венеции, тут по двору бегала не патриотично настроенная собака, а свинка, обеспечивавшая самим фактом своего присутствия гарантию того, что ни один мусульманин не решится ступить на эту землю. На фондако венецианцев, удостоенных многими путешественниками подробного описания, хранились товары разной степени экзотичности, от всевозможных медных предметов, используемых явно не в бытовых целях исключительно жителями подворья, до попугаев, некоторые из которых даже знали целые фразы по-итальянски.

Это был ключевой пункт пересечения торговых путей между Западом и Востоком, где купцы жили собственной, независимой от папских эмбарго и мусульманских предписаний, жизнью. Однако из документов Пенитенциарии мы узнаем, что в Каире и Александрии некоторые европейцы меняли веру: среди таких ренегатов, к примеру, двое уроженцев Базеля, пушкарь из Бремена, архитектор из Оппенхайма и часовых дел мастер из Аугсбурга. Приведенный список отступников и, главное, указание на их профессии заставляет исследователя задуматься о востребованности инженерных и военных профессий на Востоке.

17 В этом месте Эш ссылается на немецкое издание путешествия Феликса Фабера, Fabri (Anm. 6) 110. 
Возвращаясь к приключениям обратного пути в Европу тех, кто все же решил выполнить свой долг христианина (а заодно и купца), Эш приводит свидетельства нюренбергцев Тухера и Ритера ${ }^{18}$, что галеры были настолько нагружены, что паломникам не оставалось места на палубе. Следовательно, за место (на таком же грязном матрасе, как и по пути в Святую Землю) приходилось платить втридорога, что в принципе неудивительно, если товар, собранный на таком корабле, мог стоить в тысячи раз больше, чем оплаченная “путевка” паломника. Стоимость груза могла составлять от 30 до 80 тысяч дукатов. И эти цифры известны не только из непосредственно торговой документации: цены на специи в Александрии и Венеции и их сравнение имели весьма важное значение для тех паломников, которые на родной земле как крупные коммерсанты имели большой финансовый и политический вес. Итак, цена перца, который в Индии продавали за 1 дукат, по прибытии в Александрию увеличивалась до 7 дукатов, венецианцы покупали его за 10 дукатов, чтобы в Венеции продавать за 15, при дальнейшей логистике цена возрастала в той же пропорции. (Нужно ли объяснять, к чему конкурентам Венеции необходимость срочно обнаружить прямой путь в Индию?).

Паломнические отчеты содержат подробные описания специфических для торговли специями деталей: не только цен на сам товар, но и транспортных расходов, всевозможных издержек, налогов и пошлин, которые нужно было платить в таможенных пунктах, стоимости аренды складов, взятки и т.д. Здесь так же возникает сюжет о балансе между Востоком и Западом и движении драгоценных металлов - европейцы с времен Крестовых походов сетовали, что золото безвозвратно утекает в Индию. Однако, как замечает Эш, это представление основано скорее на литературной традиции, восходящей к Плинию, нежели отражает реальную ситуацию: в документах Каирской генизы торговые сделки Запада с Востоком выглядят совершенно иначе. В XII - XIII вв. до 90\% сделок со стороны европейцев оплачивались в неденежном эквиваленте. Таким образом, заключает Эш, особая ценность паломнических сообщений как исторических источников состоит, в частности, в том, что многие из них написаны до Великих географических открытий и представляют в удивительной степени подробности картину, сложившуюся в торговле с Востоком до открытия пути в Индию, сокрушившего монополию Венеции. Не менее важны они и для понимания границ известного мира позднего Средневековья: как раз за Египтом и Палестиной заканчивались описанные в паломнических дневниках земли и открывался простор для фантазии, которую проверить практически было невозможно (можно, но нарушив закон и предав веру). И что этим границам тоже очень скоро предстояло быть отодвинутыми. Помимо глобальных закономерностей и процессов, из этих сообщений реконструируется собирательный образ человека, отправляющегося в паломничество: его склонность и возможность к переживанию и воспроизведению этого переживания на страницах путевого дневника. Благодаря множественности сообщений исследователь может сопоставлять впечатления разных людей, плывших на одном

${ }^{18}$ Das Reisebuch der Familie Rieter (1884). 
корабле: в таком случае - получить объективное представление о тех (одних и тех же) событиях, которые они все (каждый - немного по-своему) пережили. Среди таких “параллельных сообщений” Эш приводит несколько примеров: с одной галеры в 1458 г. дневники одного итальянца и двух англичан, в 1480 г. - четверых паломников, двух французов, итальянца и немца, и четверых швейцарцев в 1519 г. Это - с одной стороны. С другой - можно попытаться типологизировать авторов сообщений, обозначив для способа их самовыражения определенные формальные рамки - вот благочестивый монах, вот храбрый рыцарь.

Однако каждый конкретный человек и его сообщение неизбежно выходит за пределы этих рамок. Среди паломников мы зачастую видим не только типаж с определенным набором интересов и особенностей, и, следовательно, тех замечаний, которые он оставил по поводу того или иного города или обычая, но и непосредственно знакомых нам исторических личностей. К примеру, отчет о поездке в Святую Землю (1523) молодого Игнатия Лойолы краток и практически лишен занятных внешних наблюдений о чудесах мира. Его паломничество всецело описывает путь души к Богу. Анализу “параллельных сообщений” с галеры 1480 г. Эш посвятил статью ${ }^{19}$ более тридцати пяти лет назад. Эти цифры дают представление о том, насколько долго можно вдохновляться одним сюжетом, продолжая дополнять и развивать свои исследования не только с точки зрения расширения источниковой базы, но и методологии.

Рассмотренная нами обзорная статья Эша весьма убедительно демонстрирует отсутствие точной границы между паломничеством и бизнесом, благочестивым долгом и поиском выгоды. Интересы рыцарей, купцов, флотовладельцев и Католической церкви постоянно пересекаются и сплетаются в удивительном феномене путешествия на Восток, и, как показывает анализируемая публикация, тема паломничества в Святую Землю в Средневековье еще далеко не исчерпана.

\section{Источники иллюстраций}

Konrad Grünemberg: Bericht über die Pilgerfahrt ins heilige Land 1486 [https://dhb.thulb.uni-jena.de/ufb_cbu_00025778 Digitale Historische Bibliotek Erfurt/Gotha].

Konrad Grünemberg: Beschreibung der Reise von Konstanz nach Jerusalem 1487 (Badische landesbibliothek Karlsruhe).

Bernhard v. Breydenbach Peregrinatio in Terram sanctam 1486 (карта Модона, рисунок взят с сайта аукциона Christie's 2018, или Кипр из эк3. ИВМ).

Тиберио д’Ассизи. Деталь фрески из Санта Мария дельи Анджели в Ассизи (creative commons license, wikipedia). 1518.

${ }^{19}$ Esch 1984:385-416. 


\section{Литература/References}

1. Das Reisebuch der Familie Rieter, hg. von R. Röhricht, H. Meisner (= Bibliothek des litterarischen Vereins Stuttgart 169) (Tübingen 1884).

2. Europäische Reiseberichte - Europäische Reiseberichte des späten Mittelalters. Eine analytische Bibliographie, hg. von W. Paravicini (3 Bd., 1994-2000).

3. Fabri - Evagatorium in Terrae Sanctae, Arabiae et Egypti peregrinationem Felicis Fabri: Hassler 1843 (lat) Roob 1965 (de)

4. Fünf Palästina-Pilgerberichte 1998 - Fünf Palästina-Pilgerberichte aus dem 15. Jahrhundert, hg. von R. Herz u. a. (Wiesbaden 1998).

5. Repertorium Poenitentiariae Germanicum. Verzeichnis der in den Supplikenregistern der Pönitentiarie vorkommenden Personen, Kirchen und Orte des Deutschen Reiches, bearbeitet von L. Schmugge und Mitarbeitern, I. Eugen IV. (1998) - XI, Hadrian VI. (2018).

6. Braunstein 2016 - Braunstein, Ph. (2016). Les Allemands à Venise (1380-1520), Rome.

7. Cardini 2005 - Cardini, F. (2005). In Terrasanta. Pellegrini italiani tra medioevo e prima età moderna, Bologna (2).

8. Die Welt des Felix Fabri 2018 - F. Reichert, A. Rosenstock (Hg.), Die Welt des Felix Fabri (Ulm 2018).

9. Esch 1984 - Esch, A. (1984). Gemeinsames Erlebnis - individueller Bericht. Vier Parallelberichte aus einer Reisegruppe von Jerusalem-Pilgern 1480, in: Zeitschrift für historische Forschung, 11, 385-416.

10. Esch 2014 - Esch, A. (2014). Fernhandel und früher Protestantismus, in: Quellen und Forschungen aus italienischen Archiven und Bibliotheken, 94, 129-142.

11. Esch 2018 - Esch, A. (2018). New sources on trade and dealings between Christians and Muslims in the Mediterranean region (ca. 1440-1500), in: Mediterranean Historical Review, 33, 135-148.

12. Protestanten zwischen Venedig und Rom 2013 - Protestanten zwischen Venedig und Rom in der Frühen Neuzeit, hg. von U. Israel, M. Matheus (Berlin 2013).

13. Richard 1981 - Richard, J. (1981). Les récits de voyages et de pèlerinages. Turnhout.

14. Schmidt 2001 - Schmidt, P. (2001), Fernhandel und römische Inquisition. „Interkulturelles Management“ im konfessionellen Zeitalter, In: Inquisition, Index, Zensur. Wissenskulturen der Neuzeit im Widerstreit, hg. von H. Wolf Paderborn, 105-120.

15. Schiendorfer 2014 - Schiendorfer, M. (2014). Daniel Ecklin ( ${ }^{\star} 1532$ - +2.1.1564): Reise zum heiligen Grab. Nach der Druckausgabe Basel: Samuel Apiarius 1575 transkribiert und kommentiert von Max Schiendorfer. 